OPEN ACCESS

Vol. 6, No. 2, October, 2018

Page. 83- 96
JOURNAL OF AUDITING, FINANCE, AND FORENSIC ACCOUNTING (JAFFA)

E-ISSN: 2461-0607 ISSN: 2339-2886

http://jaffa.trunojoyo.ac.id/jaffa

\title{
FAMILY FIRMS, AUDIT FEE, AND AUDITOR CHOICE: EVIDENCE FROM INDONESIA
}

\section{Senny Harindahyani; Celline Widjaja}

Accounting Department, Faculty of Business and Economics, Surabaya University

\section{Article Info:}

Received: 21 November 2018

in revised form: 27 November 2018

Accepted: 13 December 2018

Available Online: 22 December 2018

\section{Keywords:}

Family Firms, Audit Fee, Auditor Choice, Audit Firms

Corresponding Author:

Email: senny.h@staff.ubaya.ac.id;
Abstract; Family firms in Indonesia have an important role in the Indonesian economy. However, agency problems might happen inside family firms where it will lead to conflict of interest and information asymmetry, along with the entrenchment effect where it leads firms to produce lower quality earnings report. Research from 305 firms in Indonesia shows that the agency problems and the entrenchment effect has not affected the family firms in Indonesia, reflected from the firm's decision making in their amount of audit fee and auditor choice. This study will contribute by providing an empirical evidence of the effect of family control on the audit fee and auditor choice in a developing country. The result shows that the type of firms has no correlation on the amount of audit fee paid to the auditor and both firms' demands the same level of audit quality where it is shown by their choices of audit firms, which is Big 4 audit firm or Non-Big 4 audit firm. In conclusion, the level of agency problems and entrenchment effect tends to be lower in the family firms of Indonesia.

Abstrak; Perusahaan keluarga memiliki peran penting dalam perekonomian Indonesia. Namun, masalah keagenan yang terjadi pada perusahaan keluarga mungkin akan menyebabkan terjadinya konflik kepentingan dan asimetri informasi, serta berdampak pada entrenchment laporan laba berkualitas rendah. Penelitian dilakukan pada 305 perusahaan di Indonesia yang memiliki masalah agensi dan efek entrenchment pada perusahaan keluarga di Indonesia, yang tercermin dalam pengambilan keputusan perusahaan dalam jumlah biaya audit dan pilihan auditor. Penelitian ini akan berkontribusi ddalam memberikan bukti empiris pengaruh perusahaan keluarga terhadap biaya audit dan pilihan auditor di negara berkembang. Hasil penelitian menunjukkan bahwa jenis perusahaan tidak memiliki korelasi antara biaya audit yang dibayarkan kepada auditor dan 'tingkat kualitas audit yang ditunjukkan oleh pilihan mereka dari perusahaan audit Big 4 atau Non-Big 4. Dapat disimpulkan pula bahwa tingkat masalah keagenan dan efek entrenchment cenderung lebih rendah di perusahaan keluarga di Indonesia 


\section{INTRODUCTION}

Ninety-five percent of firms in Indonesia are family-owned firms and their wealth contributes to twenty-five percent of the Gross National Product (GNP) (CNN Indonesia, 2014). This reflects the significant influence it gives to the Indonesian Economy. As family firm has a complex structure, agency problems typically happens. Agency problem type 1, when the shareholders set the goal for the managers to achieve, but the manager shirk and do opposite actions from which the shareholders expected, leads to conflict of interest and information asymmetry (Ang, Cole, and Lin, 1999; Claessens, et. al, 2000). Agency problem type 2 is where the shareholders might have incentives to expropriate the wealth from the minority shareholders to pursue their own interest and benefits (Schulze et al., 2001).

Agency problems lead to agency cost (Collings, 2011). In addition, a firm with a family ownership in the developing country is usually affected by the entrenchment effect, where it drives the firms to produce lower quality of earnings report (Shleifer and Vishny, 1997; Gadhoum, 1999; Wang, 2014). Therefore, financial statements produced by the firm needs the assurance from an independent auditor to give credibility and reliability to the financial statements (Scott, 2015). In Indonesia, according to Undang - Undang Dasar No 5 Tahun 2011, audit firms are divided into 2 categories, Big 4 audit firms and Non-Big 4 audit firms, which consists of second-tier audit firms and local audit firms. Big 4 audit firms provide higher audit quality, shown by the higher level of assurance and credibility compared to Non-Big 4 audit firms (Scott, 2015). There is audit fee as a term of payment to obtain the audit firm's services, where IAPI (2008) stated that some factors to determine the amount of audit fee are client's need, level of expertise, responsibility, complexity of audit, audit tenure and audit fee basis.

Agency problems are believed to influence the family firms' decisions (Ho and Kang, 2013). Family firms in the developing country such as Bangladesh have a tendency to hire lower quality of auditor and pay a significant lower audit fee compared to non-family firms due to their low concern on audit (Khan, et., al, 2015). This tendency may give a bad influence on the economic development of a country, if the firm did not perform at their best. As a matter of fact, an audit should be conducted independently and fairly. Auditor should maintain their audit efforts according to the client's size, complexity and financial risk which will be followed by the audit fee (Simunic, 1980; Raghunandan and Rama, 2006). Audit conducted must be done according to the needs and conditions of the firm, when the firm becomes more complex, the audit needs to be more comprehensive and thorough, increasing the amount of audit fee, despite the fact that it is a family firm or non-family firm

Based on the explanation, the decision making matters based on the type of firms, whether it is family firms or non-family firms, is affecting the amount of audit fee they paid to auditors, and their consideration on choosing the quality of the auditor to conduct audit in their firm. This research will examine further on the companies, not including banking and financing sector, registered in the Indonesia Stock Exchange (IDX) for the period 2011 to 2014.

\section{LITERATURE REVIEW AND HYPOTHESES DEVELOPMENT}

\section{Literature Review}

There are 2 types of Agency Theory, which are type I and type II. Agency theory type I usually happened in family firms, where there is a separation of corporate ownership between corporate management and shareholders (Claessens, et., al., 2000). As the shareholders expect that the goal of the firm is to maximize their wealth, managers as the agent may shirk or take actions that are not in the best interest of the owners, leading to conflict of interest which will incur an agency cost. Ang, et., al., (1999) stated that type I agency cost for non-family firms is higher rather than in firm managed by family owners. On the other hand, there is also Agency Theory type II, where it creates an opportunity for shareholders to expropriate the wealth from the minority owners, where they are able to establish a transaction that benefits themselves at the expense of minority owners (Schulze et al., 2001). 
Wang (2006) stated that there are 2 theories of the effect of family ownership upon the demand and supply of earnings quality, which are the alignment effect and the entrenchment effect. Developed country is more likely influence by alignment effect, while Indonesia as a developing country is more likely to be influenced by entrenchment effect. Alignment effect usually happened when controlling families monitor the firm more effectively, which motivates them to report higher quality of earnings compared to non-family firms. Entrenchment effect happens when controlling families produce lower quality of earnings report for their own benefit, while the users of financial statements demand the opposite (Shleifer and Vishny, 1997; Gadhoum, 1999).

\section{Family Firm}

There is no universal definition of family firm. Shanker and Astrachan (1996) stated that a criterion used to define family business is including percentage of ownership. Martinez, Stohr, and Quiroga (2007) added that a family firm is a company whose ownership is clearly controlled by a person, a family, or a company. According to IAS 28 (IASB, 2011) and PSAK 15 (IAI, 2013), a firm is considered as a family firm if a parent company directly owned the subsidiary for more than $20 \%$ ownership of the entity and have a significant influence. While non-family firms are companies that do not meet the above criteria. Therefore, to define a family firm, it can be seen from their percentage of ownership, on whether it is held directly more than $20 \%$ by a family, a person, or a company.

\section{Audit Fee}

Audit fee is the amount of money given to the auditor as a payment for the audit services given to the companies that will be determined in the audit engagement. Wall Street Journal (2003) argues that audit fee consists of fees incurred for performing the audit and the services that generally only the independent accountant can reasonably provide, and it is different with audit-related fees, which consists of assurance and related services that are traditionally performed by independent accountant.

Some factors may determine the amount of audit fee, where IAPI (2008) has stated the fee determination policies, which there are several factors in determining audit fee, such as client's needs, statutory duties, independency, level of expertise, responsibility and complexity of audit, audit tenure and audit fee basis. Collings (2011) stated that accountants have the freedom for determining the fee, and it has to be appropriate with the level of work involved. As the level of work increases, the audit efforts will increase as well, which leads to increases in the audit fee. Therefore, audit firms shall avoid "low-bailing", which happens when the fee paid is too low and makes it difficult for auditors to perform the work necessary according to the technical and professional standards. The level of audit fee paid should be on the same level of the auditor's effort. SPAP 510 (IAPI, 2013) stated that in the audit engagement, clients and auditors have to be ensured that they have the same understanding of both the terms of engagement and the fees agreed. The client is also required to sign to confirm that they are understand on the terms of the auditors will engage, and the nature and scope of work that auditor will perform.

\section{Auditor Choice}

According to Undang - Undang Dasar No 5 Tahun 2011, in Indonesia, audit firm is divided into 2 types of audit firm, which are foreign audit firm (Kantor Akuntan Publik Asing (KAPA)) and local audit firm (Kantor Akuntan Publik (KAP)). Both foreign and local audit firm have the same services and responsibilities that they can give to their client. Foreign audit firms are those local audit firms that have affiliation with foreign audit firms, and it can be separated into 2 categories, which are Big 4 audit firms and non-Big 4 audit firms. Audit firms included as Big 4 are those who have the largest international professional services networks that offer audit, assurance, tax, accounting, advisory, actuarial, corporate finance, and legal services, as well as handle the majority audit for both publicly traded companies and private companies (Wall Street Journal, 2011). Audit firms that are not included as Big 4 audit firms are also 
known as second tier audit firms. On the other hand, there is local audit firms, which is audit firms that has no affiliation whatsoever with foreign audit firms.

Different types of companies would demand different types of auditor to audit their financial statement. However, Boone, et., al., (2010) stated that level of performance by Big 4 and second-tier audit firms are similar, since there is little difference in each of their actual audit quality. In contrary, from the perspective of the investors and most people, they perceived a large difference on their audit quality. Lawrence, et., al., (2011) stated that the audit quality performed by Big 4 and non-Big 4 audit firms are insignificantly different, and the difference exists is mainly because of the client's characteristics and client's size. From the independency perspective, the audit quality between Big 4 and second tier firm are more likely the same (Darwin, 2012). Kabir et al., (2011) also found that the insignificantly difference of the audit quality is due to the competitive audit market, where the demand for quality audit is poor, especially in developing countries.

\section{Hypotheses Development \\ Family Firms and Audit Fee}

Agency problems are believed to influence the family firms' decisions (Ho and Kang, 2013). Family firms in the developing country such as Bangladesh have a tendency to hire lower quality of auditor and pay a significant lower audit fee compared to non-family firms due to their low concern on audit (Khan, Muttakin, and Siddiqui, 2015). This tendency may give a bad influence on the economic development of a country, if the firm did not perform at their best. As a matter of fact, an audit should be conducted independently and fairly. Simunic (1980) argued that the level of client's size, risk, and complexity, no matter whether it is family firms or non-family firms, will affect on the level of audit fees. Thus, the higher the client's size, risk, and complexity will lead the auditor to increase their effort in conducting the audit, and thus higher audit fees will required (Raghunan and Rama, 2006). Audit conducted must be done according to the needs and conditions of the firm, when the firm becomes more complex, the audit needs to be more comprehensive and thorough, increasing the amount of audit fee, despite the fact that it is a family firm or non-family firm. Therefore, the first hypothesis can be taken:

$\mathrm{H}_{01}$ : There is no significant difference in audit fees between family firms and non-family firms.

\section{Non-Family Firms on Auditor Choice}

A number of studies have explored the difference of decision making for their auditor choice and the amount of audit fee paid between family firms and non-family firms. As research by Khan, et., al., (2015) and Ho and Kang (2013) shows that family firms tend to hire lower quality of auditor and pay significantly lower audit fees compared to non-family firms. While, Barontini and Caprio (2006) and Lin and Liu (2009) state that non-family firms tend to hire better quality auditor and are willing to pay higher audit fees compared to family firms.

Barontini and Caprio (2006) stated that non-family firm may perform better than family firms when there is no family represented in the board, which will give the nonfamily firms the confidence on choosing better auditor to audit their financial statements. Other than that, hiring higher quality auditor is preferred by independent boards since it will signal effectiveness of their audit monitoring and good corporate governance inside the firm (Lin and Liu, 2009). Sun and Liu (2011) argued that independent directors in the non-family firms are less likely to hire a high quality auditor, such as Big 4, in condition where many analysis and coverage is needed. Therefore, the second hypothesis can be taken:

$\mathrm{H}_{02}$ : There is no significant difference in audit fees between family firms and non-family firms. 


\section{RESEARCH METHOD}

\section{Variables Measurement \\ Dependent Variables}

There are 2 dependent variable used in this research, which are:

1. The first dependent variable for the first hypothesis is audit fee (AUDITFEE), which the amount paid from firms to auditors for delivering the audit services (Wall Street Journal, 2003). AUDITFEE as the first dependent variable is measured by taking the natural log of audit fee.

AUDITFEE $=$ Natural Log of Audit Fee

2. The second dependent variable for the second hypothesis is auditor choice (AUDITORCHOICE) and binary logistic will be used to measure between the choices of auditor, by dividing using dummy variables, which is 1 if the audit firm is Big 4 audit firms and 0 if the audit firm is non-Big 4 audit firms.

\section{Independent Variables}

The independent variable used in this research is family firm (FAMILYCON), where it is determined using dummy variables, where 1 is for family firm and 0 is for non-family firm. Martinez et al. (2007) stated that family firm is a company whose ownership is clearly controlled, where IAS 28 (IASB, 2011) and PSAK 15 (IAI, 2013) added that the control is given where a parent company directly owned the subsidiary for more than $20 \%$ of the entity.

\section{The Sample of The Study}

This research objects will cover all of go public companies, not including banking and financing sectors, registered in Indonesian Stock Exchange (IDX) for the period of 2011 to 2014, which accumulates to 1844 companies. The firms used as samples must meet the following criteria, (1) the financial statements must use Rupiah as their reporting currency, (2) the financial statements must have ended in 31st December of each year, and (3) the firm's annual report stated their auditor chosen and the amount of audit fee paid to the auditor. Hence, we have found that the total company that fits into the sample is 305 samples. It must be noted that the samples collected are using non-probability sampling and purposive judgmental sampling.

\section{Data Analysis}

The data analysis consists of statistic descriptives, classical assumption test and Multiple Regressions for the First Regression, and Binary Logistics Regression for the Second Regression.

The first regression model is as follows:

$$
\begin{aligned}
\text { AUDIT FEE }=\beta_{0} & +\beta_{1} \text { FAMILYCON }+\beta_{2} \text { FAMCEO }+\beta_{3} \text { INSIDEOWN }+\beta_{4} \text { INSTOWN }+\beta_{5} \text { GOVOWN } \\
& +\beta_{6} \text { AUDCMPLX }+\beta_{7} \text { LEV }+\beta_{8} \text { SIZE }+\beta_{9} \text { BOARDIND }+\beta_{10} \text { PROF }+\beta_{11} \text { AQ }+\varepsilon
\end{aligned}
$$

The second regression model is as follows:
FAMILYCON $=$ Show whether it is family firms or non-family firms.
FAMCEO = Show whether there CEO in the firm is family member or non-family member.
INSIDEOWN $=$ Show the percentage of shares held by non-family inside owners.
INSTOWN $=$ Show the percentage of shares held by institutional investors.
GOVOWN $=$ Show the percentage of shares held by government.
AUDCMPLX $=$ Show the complexity of the audit by taking the sum of account receivable and inventory, then scaled with total assets.
LEV $=$ Show the leverage of the firm measured by the ratio of total debt and total assets.
SIZE $=$ Show the size of the firm by taking the natural log of total assets.
BOARDIND $=$ Show the proportion of independent commissionaire in the board. 
PROF $\quad=$ Show the profitability of the firm, measured by the ratio of net income and total assets.

AQ $\quad=$ Show the quality of the auditor, using dummy variables, where " 1 " is for Big 4 audit firms and "O" is for non-Big 4 audit firms.

$$
\begin{aligned}
& \text { AUDITOR CHOISE }=y=\frac{P}{1-P} \\
& =e^{\beta_{0}+\beta_{1} \text { FAMILYCON }+\beta_{2} \text { INSIDEOWN }+\beta_{3} \text { INSTOWN }+\beta_{4} \text { GOVOWN }+\beta_{5} \text { AUDCOMPLX }+\beta_{6} L E V+\beta_{7} \text { SIZE }+\beta_{8} \text { PROF }}
\end{aligned}
$$

\section{FINDINGS AND DISCUSSION}

\section{Descriptive Statistics}

Table 1 summarizes that 305 listed companies have minimum $\ln$ audit fee of 17.5007 and maximum $1 \mathrm{n}$ audit fee of 24.4246. It means the minimum of the audit fee paid by the firm is $\mathrm{Rp} 44,000,000$ for the year 2013 and the maximum audit fee paid by the firm is $\mathrm{Rp} 40,503,000,000$ for the year 2011. The mean of the audit fee paid by firm is 20.3411 or $\operatorname{Rp~} 1,648,554,643.94$ and the standard deviation of the audit fee paid is 1.2561 . This evidence suggests that audit fee can vary based on consideration of various factors.

Table 1. Descriptive Statistics of Total Sample

\begin{tabular}{lccccc}
\hline & N & Minimum & Maximum & Mean & Std. Deviation \\
\hline AUDITFEE & 305 & 17.5997 & 24.4246 & 20.3411 & 1.2561 \\
INSIDEOWN & 305 & 0.00 & 0.2379 & 0.0107 & 0.0342 \\
INSTOWN & 305 & 0.00 & 0.6664 & 0.1844 & 0.1809 \\
GOVOWN & 305 & 0.00 & 0.9003 & 0.1084 & 0.2466 \\
AUDCMPLX & 305 & 0.00 & 0.8441 & 0.2667 & 0.2037 \\
LEV & 305 & 0.0074 & 1.1850 & 0.4554 & 0.2159 \\
SIZE & 305 & 23.4905 & 32.5790 & 28.6843 & 1.6542 \\
BOARDIND & 305 & 0.00 & 1.00 & 0.3688 & 0.1342 \\
PROF & 305 & -0.3467 & 0.3206 & 0.0617 & 0.0783 \\
Valid N (listwise) & 305 & & & & \\
\hline
\end{tabular}

\begin{tabular}{|c|c|c|c|}
\hline Variable & Dummy Variable & Frequencies & Proportion (\%) \\
\hline \multirow[t]{3}{*}{ FAMILYCON } & 0 & 87 & 28.5 \\
\hline & 1 & 218 & 71.5 \\
\hline & Total & 305 & 100 \\
\hline \multirow[t]{3}{*}{ FAMCEO } & 0 & 229 & 75.1 \\
\hline & 1 & 76 & 24.9 \\
\hline & Total & 305 & 100 \\
\hline \multirow[t]{3}{*}{$\mathrm{AQ}$} & 0 & 171 & 56.1 \\
\hline & 1 & 134 & 43.9 \\
\hline & Total & 305 & 100 \\
\hline
\end{tabular}

Table 2. Frequencies Statistics

Table 2 presents the frequency statistics of dummy variables in this research. Family Firm (FAMILYCON) is the first dummy variable in this research in which shows that there are $87(28.5 \%)$ non-family firms and 218 (71.5\%) family firms during the year of observation. Family CEO (FAMCEO) is the second dummy variable in which shows that there are $229(75.1 \%)$ listed companies that have CEO from non-family member and $76(24.9 \%)$ listed companies that have CEO from family member. Audit Quality (AQ) is the third dummy variable in this research in which shows that there are 171 $(56.1 \%)$ listed companies audited by Non-Big Four Firm and 134 (43.9\%) listed companies audited by Non-Big Four Firm. 


\section{Output of Regression}

The first model in this researh already met the criteria of the classical assumption test which includes normality test, autocorrelation test, heteroscedasticity test, and multicollinearity test. Hereafter, this study employed the multiple linear regression test to identify the result of the first hyphotesis.

The second model already met the criteria of validity test which includes the Fit Model Test and Hosmer and Lemeshow's Goodness of Fit Test.

Table 3. Multiple Regressions Table Test

\begin{tabular}{|c|c|c|c|}
\hline Model & $\begin{array}{c}\begin{array}{r}\text { Unstandardized } \\
\text { Coefficients }\end{array} \\
\text { B } \\
\end{array}$ & $\mathbf{T}$ & Sig. \\
\hline (Constant) & 9.639 & 9.449 & 0.000 \\
\hline FAMILYCON & -0.220 & -1.540 & ${ }^{*} 0.125$ \\
\hline FAMCEO & -0.387 & -3.544 & 0.000 \\
\hline INSIDEOWN & -2.731 & -2.013 & 0.045 \\
\hline INSTOWN & -0.258 & -0.888 & ${ }^{*} 0.375$ \\
\hline GOVOWN & -0.005 & -0.017 & *0.987 \\
\hline AUDCMPLX & -0.411 & -1.624 & ${ }^{*} 0.106$ \\
\hline LEV & 0.133 & 0.547 & ${ }^{*} 0.585$ \\
\hline SIZE & 0.365 & 10.387 & 0.000 \\
\hline BOARDIND & 0.470 & 1.350 & ${ }^{*} 0.178$ \\
\hline PROF & 1.025 & 1.454 & ${ }^{*} 0.147$ \\
\hline $\mathrm{AQ}$ & 0.831 & 7.514 & 0.000 \\
\hline
\end{tabular}

Based on the result of linier regression model test, then the multiple regression models will be as follows:

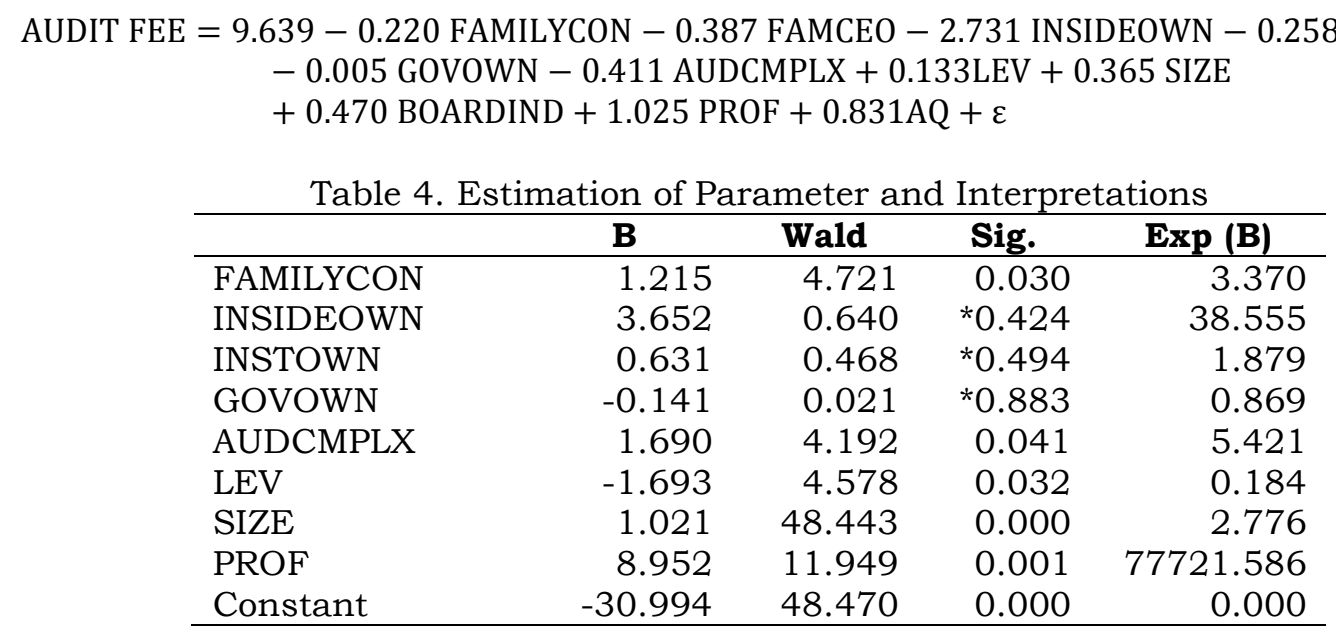

Estimation of parameter and interpretations on Table 4 stated the maximum estimation likelihood parameter of the model. The following is the logistic regression formula:

$\mathrm{y}=\frac{\mathrm{P}}{1-\mathrm{P}}$

$=\mathrm{e}^{-30.994+1.215 \text { FAMILYCON+3.652INSIDEOWN+0.31INSTOWN-0.141GOVOWN+1.690AUDCOMPLX-1.693LEV+1.021 SIZE+8.952PROF }}$

\section{Discussion}

\section{Audit Fee}

The results on Table 3 show that the first hypothesis is accepted, there is no significant difference of audit fee between family firms and non-family firms that are 
registered in Indonesian Stock Exchange (IDX) for the period of 2011 to 2014. The amount of audit fee paid to the auditor reflects on the amount of effort exerted by the auditor. In Indonesia, the amount paid by the family firm and non-family firm are according to the needs of each firms. Hassan and Naser (2013) and Ulhaq and Leghari (2015) support this findings where the client's size of business, complexity of business, and the audit firms quality, whether it is Big 4 audit firms or non-Big 4 audit firms, are significant determinants of audit fee, not the types of ownership of the stated firms. IAPI (2008) states the fee determination policy decreases the agency problems and entrenchment effect in the family firm in Indonesia. Therefore, the audit fee paid by both family firms and non-family firms are fully based on those determinants, not by its type of ownership.

Having a family member as the CEO in a firm have the tendency to lower the audit fee, which is in line with Beck and Mauldin's (2013) and Ho and Kang's (2013) research, which state that where the presence of the CEO is powerful, he or she is more likely to demand lower audit fees, despite the necessity to do otherwise. They do not want the minority shareholders to be overpowered in the Annual General Shareholders' Meetings (AGSM). On the other hand, Wang (2006) states that family firms have weak corporate governance due to the fact that a family member is the $\mathrm{CEO}$, their possession of influential position in management teams and board of directors leads to the need of higher audit effort and thus, higher audit fees.

When a non-family member became the director in the firm, the audit fee will more likely to be lower, as supported by the research by Khan, Muttakin, and Siddiqui(2015). As more non-family director as monitoring agents exist within the firm, the lower the demand for lower audit fees, since they believe that they have monitored and controlled all of the activities in the firm. if the non-family director in the family firm is few in numbers, then the number of independent parties as monitoring agent will also be fewer, necessitating an intensive audit, increasing the audit effort and thus the audit fee.

Institutional ownership has no significant impact on the audit fee. Parrino, Sias, and Starks (2003) states that institutional owner is institutional investors, including managers, directors, and regulators, as well as investment and trading institution. This findings supported with research by Ang, Cole, and Lin (1999) stated that their only concern on the financial statement is how efficient and profitable the business is, they usually do not have any expectation regarding the audit fee. Government ownership does not have a significant impact on the audit fee either, as stated by Thomsen and Pederson (2000) where they claim that government owned-firms have a strict control rights. They do not have any demand and concern on audit fee.

Audit complexity has no significant impact on the audit fee, as stated by Ahmed and Goyal (2005), who have found that the firm's financial condition and its complexity does not affect audit fee, since it is not related to the audit effort exerted by the auditor, especially in emerging economies and South Asia in particular.

Leverage has no significant impact on the audit fee, where it is supported with the research by Ashbaugh, LaFond, and Mayhew (2003) and Ahmed and Goyal (2005) which find that financing and market-to-book variables, such as leverage, don't have any association with audit fees.

The size of a firm has a significant impact on the amount of audit fee paid to the auditor. This is aligned with the previous research by Hoitash, Markelevich, and Barragato (2007), Ulhaq and Leghari (2015) and Hassan and Naser (2013). They find that the size of the client's business has significant positive relationship with audit fee. This is due to increase of audit effort, which are the labor usage and time invested of the auditor in accordance to increase in the size of the client business. Simunic (1980) also stated that the level of client's size is an important consideration for determining the audit fee, and so do Ahmed and Goyal (2005). The size of the reporting entity is one of the most important determinants of audit fee in the emerging economies, especially in South Asia.

The existence of having independence commissionaire in the board of commissionaires has no significant impact on the audit fee. Wan-hussin (2009) supported this by stating that independent commissioner is a totally independent management that does not have any relationship with the firm, they have purely 
independent judgment, and does not have any expectation and demand on the firm's audit fee.

Profitability of the firm has no significant impact on the audit fee, where it is supported by Hassan and Naser (2013) that audit fees are not influenced by client's profitability. The choice of an auditor firm is usually decided during the annual General Shareholder's meeting. Therefore it has no direct effect on the auditor's efforts and its related fee.

The quality of the auditor chosen by the company has a significant impact on the audit fee, where it is supported with research by Shaohua (2010). The research have found that a family firm are more likely to choose a better quality of auditor to signal a non-expropriation behavior than a non-family firm, which leads to higher audit fees incurred since more efforts is needed. Soyemi (2014) states that Big 4 audit firms are more likely to charge a higher or premium audit fees than non-Big 4 audit firms, where Big 4 audit firms is perceived to have better audit quality.

\section{Auditor Choice}

The results on Table 4 shows that the second hypothesis in this research is accepted, which is the demand for audit quality is not significantly higher in family firms than non family firms that are registered in Indonesian Stock Exchange (IDX) for the period of 2011 to 2014 . Both family firms and non-family firms demand a better quality of auditor to audit their firms. As Hassan and Naser (2013) and Ulhaq and Leghari (2015) stated that the client's size and audit complexity are reflecting the audit risk. Therefore, the higher the audit risk of the firm, then they will hire higher quality of auditor, such as Big 4 audit firms, otherwise, as the audit risk of the firm lowers, they will hire the quality of auditor that suits their needs. The type of firms, whether it is family firms or non-family firms in Indonesia will not influence on the firm's auditor choice. It shows that the existence of agency problem, especially the entrenchment effect, in the family firms in Indonesia tend to be lower. Therefore, family firms and non-family firms have the same demand for the level of audit quality to be conducted for their financial statement, which is show by their auditor choices.

Non-family director has no significant impact on the demand of having higher quality of auditor, where it supported with research by Ang, Cole, and Lin (1999). It states that the existence of non-family director as shareholders will decrease the monitoring and free-rider problem to occur, which will lead to increase in agency cost. Therefore, controlling shareholders will be more concerned on the agency cost when non-family director as shareholders exist and this does not affect the decision made for auditor choice.

Institutional ownership has no significant impact on the demand of having higher quality of auditor, where it is supported with research by Ang, Cole, and Lin (1999). It has been found that institutional owner is more concerned about the internal of the firm, which is the agency problem that will lead to agency cost. It will lead them to conduct more extensive monitoring on the firm in order to lower the agency cost. Thus, the existence of institutional owner only focuses on minimizing the agency cost inside the firm, it does not affect the decision made for auditor choice.

Government ownership has no significant impact on the demand of having higher quality of auditor. Thomsen and Pederson (2000) stated that government owned-firms have a strict control rights. As monitoring agents, they also do not have any demand and concern on the choices of auditor for auditing their financial statements.

The complexity of the audit has a significant impact on the demand of having higher quality of auditor, where it is supported with research by Cohen and Leventis (2013). Where inventory and accounts receivable is high, it involves a greater loss exposure in terms of audit risk, which means that the audit risk will be higher and it needs better quality of auditor.

Leverage has a significant impact on the demand of having higher quality of auditor, where it is supported with research by Khan, Muttakin, and Siddiqui (2015). The paper states that the level of leverage influence the choice of auditor, where the higher the level of leverage increase the threat of bankruptcy and loss of control. Thus, 
it will persuade the managers to avoid value-decreasing decisions by hiring better quality of auditor or Big 4 audit firms.

The size of the firm has a significant impact on the demand of having higher quality of auditor, where it is supported with research by Clement and Palacio (2015). They have found that the bigger the size of the firm, it needs more audit effort, and thus it needs better quality of auditor to audit their financial statements. Lee and Lee (2013) believes that Big 4 audit firms gives higher quality of audit, which is shown by their ability to explain more variations from the audit process. As the size of the firm gets bigger, it needs more explanation; higher quality auditor is more likely to have the ability to do the explanations. Aksu, Onder, and Saatcioglu (2007) have found that the firm size is positively and significantly associated with the choice of Big 4 audit firms.

Profitability of the firm has a significant impact on the demand of having higher quality of auditor, where it is supported with research by Lawrence, Minutti-Meza, and Zang (2011). It states that clients from Big 4 audit firm and non-Big 4 audit firms has significant difference in characteristics, one of which is profitability. Big 4 audit firm's clients have significant higher profitability than non-Big 4 audit firm's clients. As the firm has high profitability, they have more confident in hiring better quality of auditor, which are the Big 4 audit firms.

The finding in the first hypothesis and the second hypothesis are aligned with one to another, where it has been found that there is no significant difference in audit fee between family firms and non-family firms and the demand of audit quality is not significantly higher in family firms than non-family firms. Both findings are based on the reason that family firms in Indonesia, as developing country are not influenced by the entrenchment effect, where the audit conducted on the firms is conducted accordingly to the needs of the firm, which it reflects on their audit fee and auditor choice. Alignment effect is more likely to happen in Indonesia, as Francis, Khurana, and Pereira (2003) stated that it happens in a country that has a strong investor protection and higher accounting of standards. Compared with another developing country, Kabir et al. (2011) stated that Bangladesh's capital market has weak investor protection and a poor corporate regulation, which is caused by agency problem regulation that has not been addressed properly by Bangladesh Security and Exchange Commission. While in Indonesia, the regulations are more robust, Undang - Undang Dasar No 40 Tahun 2007, Otoritas Jasa Keuangan (OJK) in POJK No. 32/04/2014, and Kitab Undang - Undang Hukum Dagang, shows that Indonesia has better investor protection and corporate governance compared to Bangladesh, which makes Indonesia's firm less likely to be influenced by entrenchment effect.

\section{RESULTS AND DISCUSSION}

The study has found that the first hypothesis is accepted. There is no significant difference in audit fee between family firms than in non-family firms. It implies that the types of firms has no correlation on the specific audit effort needed by the auditor; nevertheless the audit fee is highly influenced by the size of the firm and the quality of the auditor chosen, Big 4 audit firms or Non-Big 4 audit firms.

The second hypothesis is also accepted. It stated that the demand of audit quality is not significantly higher in family firms than in non-family firms. Both firms demand the same level of audit quality to be conducted in their firms. The other factors that influence the choice of auditor are the complexity of the audit, the firm's leverage, the firm's size, and the firm's profitability.

The results from both hypotheses align with each other. It shows that the agency problem doesn't occur in Indonesian firms and the entrenchment effect has not taken place inside the family firms in Indonesia. The amount of audit fee paid is according to the audit effort exerted by the auditor during the process of the audit of the firm, and the demand for both family firms and non-family firms are on the same level, where they demand the highest level of audit quality which can be seen from their auditor choices, Big 4 audit firm or Non-Big 4 audit firm.

The findings from this research have a number of important implications for the audit market in developing countries. It will help to accommodate further works on analyzing on how the laws and regulations in Indonesia on how much the audit firm is 
paid and the engagement of the audit firm. Moreover, it will help in clarifying the standards and trends followed by the firms, so that there will be standardization in producing the financial statement, thus the financial statement produced can be more convincing and credible to the outside parties, especially investors and creditors.

This research still has some potential limitations. First, audit fee is usually voluntarily disclosed in the financial statement. However, not all go public companies disclosed their audit fees; this limits the amount of data that are able to be processed as sample. Second, the period of the research is only for 4 years, which is quite a short time period. To be able to give better conclusion, it will be better to extend the time period. Third, the variables used in this research is limited, where only 10 control variables used in the first hypothesis and 7 control variables used in the second hypothesis. Therefore, it will be better to add more variables which can help to explain the relationships with the dependent variables.

\section{REFERENCES}

Ahmed, K, and Goyal, M.K. (2005). A Comparative Study of Pricing of Audit Services in Emerging Economies. International Journal of Auditing, Vol. 9: 103-116.

Aksu, M., Onder, T., and Saatcioglu, K. (2007). Auditor selection, client firm characteristics, and corporate governance: Evidence from an emerging market. Working Paper. Sabanci University.

Ang, J., Cole, R., and Lin, J. (1999). Agency costs and ownership structure. Journal of finance, Vol. 55: 81-106.

Ashbaugh, H., LaFond, R., and Mayhew., B.W. (2003). Do non-audit services compromise auditor independence? Further evidence. The Accounting Review, Vol. 78 (3): 611.

Barontini, R. and Caprio, L. (2006). The effect of family control on firm value and performance: Evidence from Continental Europe. European Financial Management, Vol. 12(5): 689-723.

Beck, M., Mauldin, E. (2013). Who's really in charge? Audit committee versus CFO power and audit fees. Working paper, University of Missouri.

Boone, P.J., Khurana, K.I., and Raman, K.K. (2010). Do the Big 4 and the Second-tier firms provide audits of similar quality? Journal Accounting Public Policy, Vol. 29: 330-352.

Claessens, S., Djankov, S.L., and Larry, H.P. (2000). The separation of ownership and control in East Asian corporations. Working Paper. University of Cambridge.

Clement, V.C. and Palacio, J.R.S. (2015). How much does size matter in agri-food firms? Journal of Business Research, Vol. 68: 1589-1591.

CNN Indonesia. (2014, Februari 12. PwC: 95 Persen Perusahaan Indonesia adalah Bisnis Keluarga. (www.cnnindonesia.com).

Cohen, S. and Leventis, S. (2013). An empirical investigation of audit pricing in the public sector: The case of Greek LGOs. Financial Accountability and Management, Vol. 29(1): 74-98.

Collings, Steven. (2011). Interpretation and Application of International Standards on Auditing. United Kingdom: John Wiley and Sons, Ltd.

Darwin. (2012). Analisis perbedaan kualitas audit KAP Big 4 dan KAP second tier dinilai dari indepedensi auditor, manajemen laba, dan nili relevansi laba. Working Paper. Universitas Indonesia.

Francis, J., Khurana, I.K., and Pereira, R. (2003). The role of accounting and auditing in corporate governance and development in financial markets around the world. Asia-Pacific Journal of Accounting and Economics, Vol. 10(1): 1-30.

Gadhoum, Y. (1999). Potential effects of manager's entrenchment and shareholdings on competitiveness. European Journal of Operational Research, Vol. 118: 332349. 
Hassan, Y.M. and Naser, K. (2013). Determinants of Audit Fees: Evidence from an Emerging Economy. International Business Research, Vol. 6: 8.

Ho, J.L., and Kang, F. (2013). Auditor choice and audit fees in family firms: evidence from the SandP 1500. Auditing: A Journal of Practice and Theory, Vol. 32(4): 7193.

Hoitash, R., Markelevich, A., and Barragato, C. A. (2007). Audit fees and audit quality. Managerial Auditing Journal, Vol. 22(8): 761-786.

Ikatan Akuntan Indonesia. 2013. Standar Akuntansi Keuangan Per Efektif 1 Januari 2013. Jakarta: Ikatan Akuntan Indonesia.

Institut Akuntan Publik Indonesia. (2008). Surat Keputusan No KEP.024/API/VII/2008 tentang Kebijakan Penentuan Fee Audit

Institut Akuntan Publik Indonesia. 2013. Standar Audit ("SA") 510 Perikatan Audit Tahun Pertama - Saldo Awal. Jakarta: Salemba Empat

Kabir, M. H., Sharma, D., Islam, M. A., and Salat, A. (2011). Big 4 auditor affiliation and accruals quality in Bangladesh. Managerial Auditing Journal, Vol. 26(2): 161-181.

Khan, A., Muttakin, M.B., and Siddiqui, J. (2015). Audit fees, auditor choice, and stakeholder influence: Evidence from a family firm dominated economy. The British Accounting Review, Vol. xxx: 1-17.

Lawrence, A., Minutti-Meza, K., and Zang, P. (2011). Can Big 4 versus Non-Big 4 differences in audit quality proxies be attributed to client characteristics? The Accounting Review, Vol. 86(1): 259-286.

Lee, H.L. and Lee, H. (2013). Do Big 4 audit firms improve the value relevance of earnings and equity? Managerial Auditing Journal, Vol. 28(7): 628-646.

Lin, Z. J. and Liu, M. (2009). The impact of corporate governance on auditor choice: Evidence from China. Journal of International Accounting, Auditing and Taxation, Vol. 18: 44-59.

Martinez, J.I., Stohr, B.S. and Quiroga, B.F. (2007). Family ownership and firm performance: Evidence from Public Companies in Chile. Family Business Review, Vol. 20(2): 83-94.

Parrino, R., Sias, R. W. and Starks, L.T. (2003). Voting with their feets: institutional ownership changes around forced CEO turnover. Journal of Financial Economics, Vol. 68: 3-46.

Raghunandan, K., and Rama, D. V. (2006). SOX Section 404 material weakness disclosures and audit fees. Auditing: A Journal of Practice and Theory, Vol. 25(1): 99-114.

Schulze, W., Lubatkin, M., Dina, R., and Buchholtz, A. (2001). Agency relationship in family firms: theory and evidence. Organization Science, Vol. 12(2): 99-116.

Scott, W.R. (2015). Accounting Theory, $7^{\text {th }}$ edition. Pearson: Canada.

Shanker, M.C. and Astrachan, J.H. (1996). Myth and realities: family businesses' contribution to the US economy - A framework for assessing family business statistics. Family Business Review, Vol. 9(2): 107-123.

Shaohua, H. (2010). Auditor Choice, Audit Fees, and Internal Governance in Family Firms. Working Paper. Lingnan University.

Shleifer, A., and Vishny, R. (1997). A survey of corporate governance. Journal of Finance, Vol. 52: 737-783.

Simunic, D.A. (1980). Assessing audit risk from errors and irregularities. Journal of Accounting Research, Vol. 28(supplement): 110-140.

Soyemi, K.A. (2014). Clients' / Auditors' attributes and external audit fees among listed non-financial companies in Nigeria. The Business and Management Review, Vol. 5(1): 131-140.

Sun, J. and Liu, G. (2011). Industry specialist auditors, outsider directors, and financial analyst. Journal Accounting Public Policy, Vol. 30: 367-382. 
Thomsen, S. and Pederson, T. 2000. Ownership structure and economic performance in the largest European companies. Strategic Management Journal, Vol. 21(6): 689-705.

Ulhaq, A. and Leghari, M.K. 2015. Determinants of Audit Fee in Pakistan. Research Journal of Finance and Accounting, Vol. 6(9): 176-188.

Undang - Undang No 5 Tahun 2011 tentang Akuntan Publik.

Undang - Undang No 40 Tahun 2007 tentang Perseroan Terbatas.

Wang, D. 2006. Founding family ownership and earning quality. Journal of Accounting Research, Vol. 44(3): 619-656.

Wang, J.Y. 2014. Controlling shareholder entrenchment: Bonuses versus dividends. International Review of Economics and Finance, Vol. 32: 143-158.

Wan-hussin, W. N. 2009. The impact of family-firm structure and board composition on corporate transparency: Evidence based on segment disclosures in Malaysia. The International Journal of Accounting, Vol. 44: 313-333.

Wall Street Journal (WSJ). 2003. Redefined by the SEC, 'Audit fees' Get Murky. (www.wallstreetjournal.com)

Wall Street Journal (WSJ). 2011. U.K. auditors critized on Bank Crisis. (www.wallstreetjournal.com) 
